\title{
The Indeterminacy of an Emergency: Challenges to Criminal Jurisdiction in Constitutional Democracy
}

\author{
Mireille Hildebrandt
}

(C) The Author(s) 2010. This article is published with open access at Springerlink.com

\begin{abstract}
In this contribution I address the type of emergency that threatens a state's monopoly of violence, meaning that the state's competence to provide citizens with elementary security is challenged. The question is, whether actions taken by the state to ward off these threats (should) fall within the ambit of the criminal law. A central problem is the indeterminacy that is inherent in the state of emergency, implicating that adequate measures as well as constitutional constraints to be imposed on such measures cannot easily be determined in advance. This indeterminacy raises two interrelated issues. Firstly, the issue of whether it makes sense to speak of criminal jurisdiction when the existing jurisdiction is challenged as such. To what extent does the indeterminacy call for inherently unlimited powers of the state, implying there can be no such thing as criminal jurisdiction during a state of emergency? Second-if criminal jurisdiction is not in contradiction with the state of emergency - the issue of what criminal liability could mean in such a state needs to be confronted. To what extent does the indeterminacy inherent in the state of emergency jeopardise criminal liability because such indeterminacy engenders severe legal uncertainty regarding the standards against which the relevant actions are to be judged? Both issues will be discussed from the perspective of constitutional democracy, assuming that what is at stake in times of emergency is both the competence to sustain the monopoly of violence and the possibility to constrain the powers of the state.
\end{abstract}

Keywords Emergency · Indeterminacy · Criminal jurisdiction · Legal certainty · Rule of law · Radbruch · Schmitt

An earlier draft of this article was presented at the conference on 'Criminal law in times of emergency', 21-22 May 2008, Jerusalem. I thank Mark Tushnet for his comments as replier during the conference and all participants for the discussion that evolved. I also wish to thank Hans Lindahl for his salient comments to an earlier version.

M. Hildebrandt $(\bowtie)$

Erasmus University Rotterdam, Rotterdam, The Netherlands

e-mail: hildebrandt@frg.eur.nl

M. Hildebrandt

Vrije Universiteit Brussel, Brussels, Belgium 


\section{Introduction to the Issues at Stake}

In this contribution I aim to investigate the criminal responsibility of government officials for actions undertaken during a state of emergency, while also touching upon the related issue of restricting or suspending constitutional safeguards regarding the criminal law in times of emergency. The question I wish to address is against which standards officials can be judged regarding actions performed in a state of emergency. To get to this point, however, we need to face a number of related issues.

As to the criminal responsibility of government officials many questions come to mind. To what extent can, for instance, a minister of interior affairs be held liable for shooting down a civil aircraft that she considered to be an instrument of a terrorist attack? Does it make a difference whether the competence to decide on such a shooting has been attributed to him by law? Can officials justify torture by appealing to a defence of necessity and would it be possible to anticipate such a defence when writing guidelines for officials who are thereby permitted or even instructed to engage in interrogation techniques that count as torture. Should the legislator indeed provide for special competences in the case of an emergency and to what extent can a legislator anticipate which state organs or officials will need emergency powers? Does it make sense to restrict the content of such precautionary measures or does the state of emergency rule out anticipation, because its nature is unruly, chaotic and unpredictable? ${ }^{1}$ Does this mean that emergency measures can only be based on necessity? ${ }^{2}$ And if so, must we then understand necessity as a ground for justification or does this necessity rule out the distinction between justice and injustice because survival of order per se is at stake? Imagine that a transgression of legal competence attributed for cases of emergency falls within the scope of a criminal offense. Does the transgression imply that whoever violated the relevant legal norm is indeed punishable? Or should we take into account that in a state of emergency the 'normal' legal order is suspended, meaning that government officials acting during such suspension can claim immunity? Can a person be held liable ex post facto for actions performed under grotesque legal uncertainty? All these issues concern the question of whether citizens are to be protected by means of the criminal law against the potentially harmful actions of government officials in a case of emergency.

A second, related issue is the suspension of constitutional safeguards with regard to the application of the criminal law to citizens in a state of emergency. This concerns the constitutional issue of whether the legislator should have discretion to determine that in a state of emergency citizens can be detained without charges, without access to a judge within a reasonable time, without being tried in a court of law, that they can be interrogated in ways that violate the right not to be subject to inhuman and degrading treatment, that they can be convicted without access to legal counsel, tried on the basis of evidence to which they had no access. Should the decision on whether this is allowed be taken by the legislator (providing a blanket competence to specific officials, or allowing the administration to rule by decree), or even by a member of the executive (a minister), a public prosecutor or a member of the secret service, if necessity so requires? To what extent can and should such a decision be made accountable in a court of law, or in the parliamentary assembly after the state of emergency has ended?

\footnotetext{
${ }^{1}$ Schmitt (2005), at 7: 'The precondition as well as the content of jurisdictional competence in such a case [of emergency, mh] must necessarily be unlimited'.

${ }^{2}$ Necessitas non habet legem, footnote 1 of George Schwab, at p. 5 of Schmitt (2005). Also Agamben (2005) at 24-32.
} 
Who decides on the state of emergency? $?^{3}$ To what extent does the state of emergency invite its own prolongation? Could it be that providing for the possibility of a state of emergency in fact generates a state of exception that becomes the rule? ${ }^{4}$

These issues can be discussed from a variety of legal,- - theoretical, political, historical and philosophical backgrounds. I have found inspiration in the work of a number of legal and philosophical scholars who wrote around the time of the Weimar Republic, notably Schmitt and Radbruch. The urgency of the situation in which they found themselves in the wake of the Nazi take-over provided salient insights, even if one does not agree with their analysis. The pitfall of taking this perspective may be that so many have gone this road, establishing an interpretive community it would take years to join. My purpose is to validate some of the salient insights generated by some of these scholars for the relationship between indeterminacy, emergency and criminal jurisdiction. I hope to do this without reiterating longstanding discussions about whether Radbruch was converted to natural law after the war, or about whether taking Schmitt seriously equates with favouring decisionism.

In the section on Defining a case of emergency I will briefly look into different perspectives from which one could define a case of emergency, after which I will start with the ad hoc perspective of whoever 'decides on the exception', confronting Schmitt's decisionism with Kelsen's normativism as separate elements of the law. I will argue-against both - that norms and decisions are mutually constitutive, and that they both build on and produce moments of discretion. Such discretion is intensified in a state of emergency, due to its indeterminacy, but this does not imply unlimited powers for whoever seizes the power to intervene. I suggest that criminal jurisdiction, for this reason, is not by definition impossible, but the question remains whether it makes sense. To investigate this, in Issues of criminal jurisdiction for emergency interventions I will explore the meaning of punishment in a state of emergency from the perspective of utilitarian, retributive and communicative theories of punishment. This exploration raises the question of the relationship between legal certainty, justice and the public good, Radbruch's key antinomian ideas of what the law stands for. In Jurisdiction in a legal vacuum? I will then answer two interrelated questions: (1) to what extent does the indeterminacy of an emergency call for inherently unlimited powers?, (2) if this is not the case and criminal jurisdiction is thus not impossible, what does criminal jurisdiction mean if the legal order is in fact suspended? In Conclusions: judging against which standards? I will conclude with a discussion of the problem of legal uncertainty with regard to the standards against which an incriminated action is to be judged.

\section{Defining a Case of Emergency}

\section{Introduction: Perspectives}

How can we define a case of emergency that calls for extraordinary measures that may impact criminal jurisdiction? I can think of many relevant perspectives from which this

\footnotetext{
${ }^{3}$ See the famous first sentence of Schmitt (2005) at 5: 'Sovereign is the one who decides on the exception' (Soverän ist er, wer über den Ausnahmezustand entscheidet). This is taken to refer to both the decision of whether a state of exception is at hand and of what measures are to be taken, cf. Strong in her Foreword in Schmitt (2005), at xi-xii.

${ }^{4}$ Many authors on this subject refer to Walter Benjamin's thesis VIII in idem, On the concept of history, in volume 4 of Benjamin et al. (1996), at 697: 'The tradition of the oppressed teaches us that the 'state of exception' in which we live is the rule'.
} 
question can be answered: (1) the perspective of whoever finds herself in a position to take such measures (ad hoc perspective), (2) the perspective of a legislator that wishes to regulate such measures by attributing the competence to take such measures or by enacting legal norms to constrain the exercise of this competence (ex ante perspective) and (3) a citizen who wants to establish what counts as a such a case of emergency in order to further discuss which measures are warranted (ex ante perspective). Other perspectives concern (4) those of the court that is required to rule on the lawfulness of the measures or their exercise (ex post perspective) and those of a scholar of criminal or constitutional law who is asked to develop a position on relationship between a case of emergency and criminal jurisdiction (trying to imagine ad hoc, ex ante as well as ex post perspectives). Since we are discussing an emergency that warrants unusual measures by the state that are not lawful under normal circumstances, I will assume that we are dealing with a situation that is a threat to the fundamental security of citizens. I will also assume that if a state is not capable of providing an adequate response to the threat it faces, a break down of its 'raison d'état' can be expected and a challenge to its monopoly of violence. ${ }^{5}$ In the case of terrorism the threat itself already constitutes such a challenge and an inadequate response will invite a type of vigilance that further erodes the state's monopoly of violence.

In trying to imagine what counts as a case of emergency we stumble on a paradox: in the end the first-ad hoc-perspective seems to have a peculiar priority since whoever decides to take emergency measures in fact defines-concretely-what is an emergency and what it calls for. The definition in that performative sense of the term is not so much a scholarly or even a lawyerly exercise but the taking of a decision that makes a difference to all those that hope to survive.

\section{The Decision on the Exception}

Whoever wishes to write about emergency seems 'doomed' to discuss Carl Schmitt. Schmitt's penetrating and controversial discussions of the relationship between law and the political, entailing a challenging criticism of liberal democracy, have influenced a number of scholars of political and legal theory. The relevance of his work for contemporary issues of emergency (environmental, economic, terrorist) is reflected in the work of Agamben, Hardt \& Negri, Mouffe, Kennedy, Dyzenhaus and many others. Schmitt was a leading scholar of public law during the Weimar Republic (1919-1933) who got involved in the Nazi regime that took over (1933-1945) after Hitler was assigned the position of Chancellor by the Republic's President. ${ }^{6}$ One of the factors that may have decisively influenced the Nazi take-over and its sustained emergency rule was the usage of art. 48 of the Weimar Constitution, ${ }^{7}$ which granted crucial emergency powers to the Republic's President. ${ }^{8}$ In

\footnotetext{
5 For a history of the idea of the 'reason of state', see the seminal work of Meinecke (1998).

${ }^{6}$ For a short history of the Weimar Republic: Peter Gay (2001) at 147-164.

7 This is not to suggest that the Nazi take-over was the necessary consequence of the weaknesses of the Weimar Constitution, cf. Gay (2001) at 2 (referring to the 'easy pessimism' that sees 'the Republic as doomed from the start').

8 Art. 48 reads: (1) If a state does not fulfill the obligations laid upon it by the Reich constitution or Reich laws, the Reich President may use armed force to cause it oblige. (2) In case public safety is seriously threatened or disturbed, the Reich President may take the necessary measures to reestablish law and order, if necessary using armed force. In the pursuit of this aim, he may suspend the civil rights described in articles $114,115,117,118,123,124$ and 153, partially or entirely. (3) The Reich President must inform the Reichstag immediately about all measures taken based on paragraphs 1 and 2 of this article. The measures must be suspended immediately if the Reichstag so demand. (4) If danger is imminent, the provincial
} 
1922 Schmitt published his famous Political Theology on the relationship between law, state, sovereignty and the state of exception. ${ }^{9}$ While defining the sovereign as 'the one who decides on the exception' Schmitt stipulated that this decision places the sovereign beyond the (rule of) law, deciding in a non-legal moment of undivided sovereignty if and when the law will or will not rule. According to Schmitt, this non-legal intervention does not depend on whether or not the legal order provides for such a decision. It depends on 'the power of real life' that 'breaks through the crust of a mechanism that has become torpid by repetition'. ${ }^{10}$ Should we understand 'the power of real life' as the necessity that calls for an immediate intervention whereby adherence to the law becomes entirely irrelevant? Or does this 'power of real life' refer to the seizure of public power by whoever is from that moment onwards the sovereign, irrespective of whether any necessity can be established? With Schmitt the power of definition lies with whoever decides on the exception, suggesting that the necessity that calls for emergency measures and the decision to take them are inextricably intertwined: there is no objective perspective from which to establish the existence of such necessity, which is actually constituted in the decision to act on it.

One of the core tenets of his work is that this decision does not fall within the scope of a legal norm. Its regulation cannot be anticipated.

[E]very legal order is based on a decision, and also the concept of the legal order, which is applied as something self-evident, contains within it the contrast of the two distinct elements of the juristic - norm and decision. Like every other order, the legal order rests on a decision and not on a norm. ${ }^{11}$

It seems that Schmitt recognizes normativity as an essential element of the legal or juristic order, even though he grants priority to a second essential element: its decisionist nature (which he claims to be essential for any type of order). According to Schmitt, in normal times the legal order regulates by combining norms and decisions, while in a case of emergency, decisions are needed that no longer follow pre-existing rules, requiring what he calls an 'exacting moral decision' that is political rather than legal. ${ }^{12}$ The impossibility to determine in advance how this decision takes shape, implies-he states-unlimited powers for whoever decides on the exception:

What characterizes an exception is principally unlimited authority, which means the suspension of the entire existing order. In such a situation it is clear that the state remains, whereas law recedes. Because the exception is different from anarchy and chaos, order in the juristic sense still prevails even if it is not of the ordinary kind. ${ }^{13}$

Footnote 8 continued

government may, for their specific territory, implement measures as described in paragraph 2. These steps may be suspended if so demanded by the Reich President or the Reichstag. (5) Further details shall be established by Reich legislation.

9 Schmitt (2005) (the adjective 'theological' derives from Schmitt's claim that the powers of the omnipotent sovereign must be seen as the secularization of God's omnipotence, meaning that the decision on the exception interrupts normal affairs just like God's miracles were supposed to interrupt the laws of nature; he equates the idea of the constitutional state to the advent of deism, which ruled out any supernatural interference with the mechanistic causality assumed by modern science, cf. idem at 36).

${ }^{10}$ Schmitt (2005) at 15 .

11 Schmitt (2005) at 10 .

12 Schmitt (2005) at 65 . The morality of the decision resides in the fact that a real, personal choice must be made about who (or what?) is the enemy that must be fought. This is the difference with decisions informed by 'organizational-technical and economic-sociological' mechanisms, which require no such choice.

13 Schmitt (2005) at 12. 
The state of emergency - for this reason-is not a matter of chaos and anarchy, which could have prevailed if no decision was taken. ${ }^{14}$ Instead, the decision on the exception produces its own normativity, either by creating a temporary order that will allow a return to the suspended legal order or by creating a new legal order that replaces the former. In the first case Schmitt speaks of a 'commissarial dictatorship', in the second case he speaks of 'sovereign dictatorship'. ${ }^{15}$ It should be obvious that the demarcation line between commissarial and sovereign dictatorship is analytically crucial and practically porous. The terrorist attacks of 9/11 have triggered a series of emergency measures-legal, non-legal as well as illegal-deemed necessary to sustain constitutional democracy. In as far as these measures violate constitutional safeguards or democratic transparency they suspend the legal order they intend to sustain. In that sense they could be described as 'commissarial' measures. However, many of these measures have in fact generated more permanent changes in the systems of checks and balances within the existing legal orders, raising the question of whether the decisions on these measures share some characteristics with 'sovereign' dictatorship, ${ }^{16}$ creating a situation in which the exception becomes the rule. $^{17}$

\section{Norm, Decision and Discretion}

Summarising, Schmitt has elaborated two crucial distinctions with regard to the issue of the indeterminacy of an emergency: (1) by separating the legal norm from the legal decision he reminds us of the political element in the decision on the exception, ${ }^{18}$ (2) by distinguishing emergency measures aiming for a return to constitutional democracy from those fitting an agenda that erodes constitutional democracy he reminds us of the necessarily discretionary powers of whoever decides on the exception. From the perspective of Schmitt the

\footnotetext{
${ }^{14} \mathrm{Cp}$. Agamben (2005) at 65-73 (arguing on the basis of Roman law during the Republic that the state of emergency [iniustitia] is not so much a reaction against the anxiety stemming from a crisis of norms ['anomic terror'] but rather the mobilization of those in power against a possible uprising [tumultus]).

${ }^{15}$ McCormick (1998) (discussing the evolution in Schmitt's thoughts on the difference between commissarial and sovereign dictatorship, claiming that in his earlier work Schmitt advocated the use of constitutional emergency powers to uphold the Weimar Constitution against both fascism and Marxist anarchism).

${ }^{16}$ The incremental but permanent erosion of constitutional safeguards is described, for instance, by Zöller (2004) (pointing out that many security measures that were triggered by the $9 / 11$ attacks on the World Trade Center seem to continue an already established political agenda, seizing the opportunity to justify a shift from repressive to preventive measures). See also Agamben (2005) at 21 (discussing the current preference of governments to have exceptional laws issued instead of declaring the state of exception).

${ }^{17}$ Cf. Walter Benjamin et al. (1996). Benjamin refers to the usage of art. 48 of the Weimar Constitution of 1919, which allowed the president of the empire to declare a 'state of emergency', for economic emergencies. See Maus (1998) (on the economic background of the usage of emergency measures in the Weimar Republic) and Scheuermann (1994) at 123-155 (discussing Franz Neumann's 'monumental study of the anatomy of German fascism, Behemoth: The Structure and Practice of National Socialism' (1942), idem at 123, stressing the hegemony of monopolist capitalism over law in Nazi Germany, thereby opposing Horkheimer's and Pollack's model of state-capitalism). Likewise on 'the modern tendency to conflate politico-military and economic crises', Agamben (2005) at 15.

${ }^{18}$ For Schmitt 'the political' refers to the distinction between friend and enemy, cf. Schmitt (1996). This essentially regards external sovereignty. In deciding on the exception one defines the enemy, perhaps even within the confines of the national state (as in the case of civil war). For a pluralist elaboration of Schmitt's distinction see Mouffe (2000), 'Carl Schmitt and the paradox of liberal democracy', at 36-59 (further distinguishing between enemy and adversary, integrating Schmitt's criticism of liberal democracy into a theory of pluralist liberal democracy).
} 
definition of a case of emergency is in the hands of whoever seizes the opportunity. After this seizure the legal order is suspended and we can never be sure whether this seizure will transform the jurisdiction into an unconstitutional 'legal' order or safeguard the core tenets of constitutional democracy by making itself accountable after the fact. ${ }^{19}$ Emergency measures imply a loss of control, inherent in the unpredictability and radical indeterminacy of the threat to security which triggered them.

Against Schmitt, however, I argue that the legal norm and the legal decision cannot be separated, since they are mutually constitutive. This mutual determination is not exhaustive, meaning that every legal decision contains an element of creativity and every legal norm develops its meaning in the course of its history, which is-due to the creative element in the decision-underdetermined. This implies that the extreme position of the decision on the exception is rule-bound, even if the rule it embodies differs substantially from the one it violates. The discontinuity is more radical than in ordinary legal decisions, but this should not persuade us to understand the decision on the exception as one in a normative vacuum. Similarly, the loss of control inherent in the decision on the exception is present in every legal decision, to the extent that competence is attributed to specific authorities to speak the law (by ruling on a case, enacting legislation or acting within their administrative competence). Again, the loss of control is more radical than in ordinary legal decisions, but this should not be taken to mean that discretion implies a licence to act for 'le bon plaisir du prince'. ${ }^{20}$ Schmitt's emphasis on the decision instead of the legal norm was directed against Kelsen's pure theory of law. ${ }^{21}$ Kelsen's legal norm is an abstract general rule that is part of a system of legal rules, which seems to be entirely detached from real life. The decision on its application did not interest Kelsen as a legal scholar, meaning that he-too-separated norm and decision. In a less formalist positivist conception of legal norms, we are-however-bound to acknowledge that norms and actions co-determine each other. ${ }^{22}$ The actual meaning of a legal norm depends on the network of decisions about its applicability in concrete cases, and the story that unfolds in the chain-novel that is developed by successive instances of case law demonstrates how norm and decision inform each other. ${ }^{23}$

\footnotetext{
19 There is an interesting analogy with Lon Fuller's Speluncan Explorers (1949), in the sense that it provides a salient example of an emergency during which — some would claim—-the 'ordinary' legal order is suspended or absent. The difference, however, is that in this contribution we are discussing the criminal liability of government authorities that are not only concerned with survival of their own person but primarily with the survival of the state, its monopoly on violence and-hopefully-its constitutional and democratic core.

${ }^{20}$ As in eighteenth century police states, cf. Chevallier (1994), at 16.

${ }^{21}$ Cristi (1984) (indicating that Schmitt followed Hobbes' auctoritas non veritas facit legem against Kelsen's system of general abstract laws; claiming that Schmitt's position was against democracy rather than classical liberalism, thus having more in common with Hayek than the later would care to acknowledge).

${ }^{22}$ Cf. Taylor's (1995) interpretation of Wittgenstein and Winch (1958), at 57-62. Both Taylor and Winch explain how rules are implicit in our actions, which would not make sense without the tacit reference to a rule that may in fact be posited by the action. This indicates that rules do not necessarily pre-exist an action, but to make sense of an action some continuity must be established beyond the singularity of an individual act.

${ }^{23}$ Dworkin (1991), at 228-238, part of his theory of interpretation 'Integrity in Law', at 225-275. Cp. Fish (1982) (claiming that all authors in the chain are equally constrained, refuting the constraints of precedent). It would be interesting to investigate to what extent Fish gives priority to the decision above the norm.
} 


\title{
Issues of Criminal Jurisdiction for Emergency Interventions
}

\author{
Introduction: The Meaning of Punishment
}

To suggest that state authorities are liable under the criminal law for actions undertaken during a state of emergency implies that the constitutional order is restored. If the principle of legality is part of the constitutional order, this rules out criminalising ex post facto of actions not falling within the ambit of the criminal law when the acts were committed. Before moving into the consequences of the principle of legality if an emergency in fact suspends the existing jurisdiction, we must first investigate whether it makes sense to punish a person for actions performed under the pressures of an emergency. To answer this question we need to come to terms with the meaning of punishment in constitutional democracy, after which we can look into the extent to which this meaning holds when the legal order is in fact suspended. I will discuss deterrence, retribution and communication as relevant perspectives on the meaning of punishment, tracing their implications for the punishment of wrongful interventions of government officials during an emergency. This discussion will yield pertinent questions as to the role of punishment in the establishment of legal certainty and the role of legal certainty for the exercise of the ius puniendi. To elaborate this I will explore Radbruch's salient description of the fundamental antinomies that constitute the core of the law: legal certainty (without which law would be equivalent with either arbitrary tyranny or a morality without teeth), justice (without which law would be equivalent with either bureaucratic discipline or arbitrary tyranny, and purposiveness (without which law would be equivalent with morality without teeth or bureaucratic discipline). This will enable us to finally investigate the central question of this article: does criminal jurisdiction make sense in a legal vacuum?

\section{Accountability Ex Post Facto: Making Sense of Punishment}

If deterrence is the main target of punishment the indeterminacy of the emergency and the indeterminacy of what the situation calls for may render the threat of punishment wholly ineffective. If I have no idea how my behaviour will be qualified in a court of law I will not be deterred from violating the criminal law for the simple reason that I cannot determine how it relates to my actions. Instead of deterred I may be terrified, due to the uncertainty of how I will be judged. This may even paralyse me into refraining from any decision on the exception that I may still feel is at stake. I may thus abstain from taking measures I actually deem necessary, or act out of a sense of necessity without having a clue as to whether this action will be evaluated as wrongful at a later point in time. If the only criterion of deterrence is its effectiveness, as in utilitarian theories of punishment, the punishment of 'wrongful' interventions under such uncertainty must be rejected. As Schmitt would have it, a state of emergency is beyond 'wrong' and 'right' even if it may produce a new understanding of what is 'wrong' and what is 'right'.

If we take retribution to be the main target of punishment the indeterminacy of the emergency will raise altogether other issues. How can punishment be justified if no general rules are available to guide my behaviour at the moment of crisis? Is it possible to combine retribution with the radical co-creation of norm and decision that seems to be at stake in the state of emergency? Interestingly, retributivism seems to require a pre-existing general legal norm whereas deterrence could live with an ad hoc situational legal norm, as long as its content is clear and will be recognised by the court that exercises jurisdiction when the state of emergency is terminated. As we noted above, however, as long as this is not clear, deterrence will not work. 
For a retributive theory of punishment we need an assessment of the extent to which 'necessity' rules the state of emergency, and of what this means. In his discussion of the concept of necessity as the foundation of the state of exception, Agamben explains two opposing interpretations of the adage necessitas legem non habet (necessity has no law): it can be understood as either 'necessity does not recognise any law' or as 'necessity creates its own law'. ${ }^{24}$ In as far as an emergency requires violating the law out of necessity, this may be seen as either a ground for justification or as a source of new law. Building on the distinction between 'commissarial' and 'sovereign' emergency measures, we could rephrase: in as far as these measures are born from necessity they either find their justification in the necessity (justification in terms of the suspended legal order) or they ground new legal norms on this necessity (potentially positing a new legal order). This raises interesting questions about the legal order that will hold a person accountable after the state of emergency has been terminated: to what extent can the present legal order anticipate criminal responsibility in a new legal order? In my opinion retributive theories of punishment would have a serious problem with the idea of an emergency that creates-or allows the creation of-new legal norms. As long as retribution depends on a pre-existing legal order it is difficult to hold government officials responsible for interventions undertaken when the legal order is breaking down.

While retributivism is more concerned with the theoretical justification of punishment, utilitarianism seeks to establish its theoretical effectiveness. Nevertheless, both retributivism and utilitarianism seem to take a theoretical and rationalist perspective, aiming to establish universally valid criteria to determine when punishment makes sense. ${ }^{25}$

I will now argue a third understanding of the meaning of punishment, which could be termed a relational theory of punishment as coined by Foqué and 't Hart or a communicative theory of punishment as coined by Antony Duff. ${ }^{26}$ What strikes me as particularly relevant is the reciprocal as well as inclusive nature of such an understanding of punishment. ${ }^{27}$ To be effective as well as justified punishment needs to be understood as a particular type of - nondeliberative-communication. ${ }^{28}$ Punishment, or hard treatment, imposing a sanction beyond the measure of compensation for harm caused, communicates censure, thus re-establishing the normative force of the violated legal norm. This implies more than just expression of

\footnotetext{
24 Agamben (2005) at 24.

25 If we distinguish between utilitarian and pragmatist consequentialism, deterrence in itself does not presume a utilitarian approach. As mentioned, utilitarianism-like retributivism-relies on theoretical propositions. In the case of utilitarianism these propositions depend on calculations in terms of aggregated preferences, based on a separation of means and ends. Pragmatist consequentialism, however, does not take preferences as given and does not believe that means and ends can by definition be defined independently. Cf. Dewey (1916).

${ }^{26}$ Cf. Foqué and 't Hart (1990), who developed a relational theory of law to explain the counterfactual nature of the basic concepts of (criminal) law in constitutional democracy. Cf. Duff (2001). Whereas Duff rejects consequentialism, which he equates with various types of utilitarianism, I favour a pragmatist type of consequentialism that takes into account the moral implications of punishment. In that case punishment is seen as a means in terms of its end. This implies that I have no problem with deterrence, if it entails a normative appeal to uphold the legal norm as a standard between citizens and not only a means to coerce subjects into compliance with a norm imposed by a government.

27 Duff (2001) at 75-77 (discussing different types of inclusion, arguing that criminal punishment must in its nature be inclusionary) and 79-82.

${ }^{28}$ Duff (2001) at 82 (arguing that only a communicative theory can provide complete justification of punishment as hard treatment). One could say that by imposing 'hard treatment' the legal order communicates non-verbal censure, notwithstanding the deliberation that should precede and accompany conviction. One could claim that punishment as ultimum remedium is only justified when deliberation has broken down or must be deemed an inadequate response to an act of violence against the legal order.
} 
censure. ${ }^{29}$ To 'work' such communication must concern the relationship between the one in authority (holding the ius puniendi) and the subject who violated a legal norm as well as the relationship between the one in authority and all those that share jurisdiction (as potential victims and potential offenders). ${ }^{30}$ If this communication 'works' the violated legal norm will be re-established as a norm that regulates the relationships between all those that share jurisdiction (not only as a norm that regulates the relationship between a state and its individual citizens). Legal norms - from a communicative perspective — set the standards for justified expectations of behaviour between citizens (and between citizens and state officials). They open a space for interactions that build on mutual trust, at least in as far as the violations of legitimate expectations can be brought before a court of law, thus re-establishing the normative force of the legal norm and re-establishing the precondition for mutual trust in the public as well as the private sphere. From this perspective legal certainty is as crucial as justice and effectiveness to the idea of law. Does this mean that a communicative theory of punishment rules out punishment in a case of emergency when legal certainty actually breaks down? Before moving into this point in the last section, I shall extend the analysis to the relationship between legal certainty, justice and the public good, taking the perspective of another famous legal scholar of the Weimar Republic: Gustav Radbruch. ${ }^{31}$

\section{Legal Certainty, Justice and Public Good}

According to Gustav Radbruch the challenge of the law is to actualise the balance of three-often antinomian - aspects of legal decisions that determine the application and the meaning of legal norms: justice, legal certainty and purposiveness. ${ }^{32}$ In coining these aspects as antinomies Radbruch seems to indicate that their relationship cannot be fully determined in advance: their relationship cannot be stipulated by rules (nomos) that require only mechanical implementation. This implies that the legal decision is underdetermined by the legal norm, even if norm and decision unavoidably co-constitute each other from the perspective of what it is 'to follow a rule'. ${ }^{33}$

For the punishment of emergency interventions by government officials, legal certainty is crucial. Schmitt's insight that this legal certainty is at stake during a case of emergency is confirmed by Radbruch's stress on this aspect of the law. Referring to Schmitt, he writes:

The order of living together cannot be left to the particular conceptions of law of individual citizens, as different people may well have contradictory ideas, requiring a unitary regulation from a supra-individual position. (....) If nobody can establish what is just, somebody must decide, what should be lawful, and positive law should fulfil the assignment, to end the contradictory conceptions of law by means of an authoritative verdict. The positiveness of the law must depend on a will that can impose itself against any contradictory conception of law. ${ }^{34}$

${ }^{29}$ Duff (2001) at 79-80 (stressing the reciprocal and rational engagement of communicative understanding of punishment: appealing to the reason and understanding of the recipient of punishment).

${ }^{30}$ On this conception of punishment, norm and action see Hildebrandt $(2002,2006)$. On the related expectancy theory of legal norms see Glastra van Loon (1958).

${ }^{31}$ Radbruch was Minister of Justice in the Weimar Republic from 1921 to 1922 and 1923, a member of the Social Democratic Party, and professor of criminal law and legal philosophy at Königsberg, Kiel and Heidelberg.

32 Radbruch (1950), at 168-174. See also Leawoods (2000).

33 Cf. Taylor and Winch supra note 22.

${ }^{34}$ Radbruch (1950) at 179, translation Mireille Hildebrandt (MH). 
Interestingly, his reference to Schmitt suggests that the legal decision (entailing the positive character of the law) cannot be reduced justice, ${ }^{35}$ without, however, concluding that the decision to posit the law has no relationship to what is just and purposive. In his discussion of the antinomian character of the idea of law, he writes:

Justice requires us only to treat equal cases as equal and unequal cases as unequal, however, it does not provide us with the perspective from which they can be seen as either equal or unequal; it furthermore only provides us with the relationship, but not with the content of the treatment. Both questions can only be answered on the basis of the purpose of the law. ${ }^{36}$

After observing that the purpose of law (which he qualifies as the public good) is a matter of differing opinions, ${ }^{37}$ he concludes that this calls for a decision on the content of the law that is binding even on those that would not agree. This conclusion confirms a certain priority for legal certainty — as in the text quoted above-and I will now quote the original German text to highlight the intricate nuances in his usage of German:

Die Sicherheit des Rechts fordert Positivität des Rechts: wenn nicht festgestellt werden kann, was gerecht ist, so muss festgesetzt werden, was rechtens sein soll und zwar von einer Stelle, die, was sie festsetzt, auch durchzusetzen in der Lage ist. ${ }^{38}$

It seems that Radbruch agrees with Schmitt that any order is always better than no order, and that law in the end depends on the power to decide and enforce the law when agreement on its content cannot be reached. What is the relevance of this position in the case of an exception, when the monopoly of violence itself is at stake? Does Radbruch agree with Schmitt that in such a situation the law is suspended and the juristic order reduced to a pure and simple decisionism? To answer that question we can best look into his 'Five minutes of legal philosophy', published at the end of the war in 1945, which gave occasion to the famous debate between Hart and Radbruch about the 'guilt' of legal positivism during the rule of National Socialism. ${ }^{39}$ My interest here is the meaning of Radbruch's position for criminal responsibility of government officials in times of (extended) emergency.

\footnotetext{
35 Radbruch (1950) at 179, footnote 1: '(Such a theory of legal force has been called decisionism by Carl Schmitt. He recognizes this most clearly in Hobbes [auctoritas, non veritas facit legem], cf. 'Die drei Arten des rechtswissenschaftlichen Denkens', 1934, at 27, also 35 [at the same time decisionism and normativism])', translation MH. Radbruch refers to Schmitt's 'Ueber die drei Arten des rechtswissenschaftlichen Denken' of 1934, published in Hamburg: Hanseatische Verlagsanstalt.

36 Radbruch (1950) at 168, translation MH. Radbruch speaks of Zweckmässigkeit (purposiveness), which should however not be understood as effectiveness per se. It concerns an orientation towards the public good, which can be defined in different ways, depending on one's political views. See 'Der Zweck des Rechts' (the purpose of law), idem, at 146-155. In later work he speaks of the Gemeinnutz as Ziel des Rechts (common interest as the purpose of law), see idem, at 336.

37 Liberals may claim that individual freedom is the core of the public good (individualist conception of the public good), communitarians may opt for collective values, personified in the Nation (supra-individualist conception of the public good), while still others may seek the public good in cultural identifications (transpersonal conception of the public good), cf. Radbruch (1950) on 'Der Zweck des Rechts'.

38 Radbruch (1950) at 169, all italics are in the original (differentiating between feststellen and festsetzen to emphasise the difference between consensus on the basis of a free discussion and a decision that has force of law; and differentiating between festsetzen and durchsetzen to emphasise the fact that law is not only about enacting legislation but also about being capable to enforce of law).

39 See for instance Fuller (1985) (discussing Hart's argument against Radbruch's relativization of positivism, claiming that while reproaching Radbruch a move from 'is' to 'ought', his own position about the difference between law and morality is unclear at precisely this point, and advocating the 'inner morality of order', while distinguishing between 'order' and 'good order').
} 
In his first minute, Radbruch clarifies that the positivist emphasis on 'Gesetz ist Gesetz' and the subsequent emphasis on the power to enforce the law as the only valid criterion to speak of 'law', has left lawyers as well as citizens without resistance against arbitrary laws, however, terrifying and criminal they may have been. In his second minute, Radbruch discusses the idea of 'Recht ist, was dem Volke nützt' (law is what is in the interest of the people, mh), indicating that this often means that whatever those in power claim to be of interest for the people, is imposed as law, however, arbitrary, in violation of existing laws and harmful it may be. In his third minute, Radbruch then comes to the point: when laws are no longer oriented towards justice, for instance suspending human rights in an arbitrary fashion and thus no longer treating equal cases in an equal manner, lawyers should find the courage to reject these laws as 'law' ${ }^{40}$ In his fourth minute, Radbruch extends this invalidation of certain laws to those laws that cannot be understood as aiming for the public good. As in the case of laws that are not oriented toward justice and equal treatment, he denies such laws their character as 'law'. Note that his point is not that for laws to be recognised as 'law' they must be found to realise justice and the public good. As recounted above, positive law is important because it can decide on what is lawful precisely because people do not agree on the content of justice nor on the content of the public good. It is only in the extreme case of laws not even aiming for justice or the public good, that we should invalidate them as 'law'. ${ }^{41}$ In his fifth minute, Radbruch argues that there are fundamental legal tenets that overrule laws that contradict these tenets. Though he seems to categorise such tenets as a part of natural law he then indicates that we must seek these fundamental legal tenets in the human rights and citizens rights that have developed over the past centuries, thus emphasizing the historical and cultural nature of these overruling characteristics of 'law'. This means that he is not discussing 'law' in general but the 'law' of a constitutional democracy. Radbruch is not trying to establish the rational and universal conditions of what is 'law', he is arguing for ways to sustain the fragile historical artefact of the rule of 'law' in the face of its most extreme challenges. In that sense I am not sure that positivists like Hart are discussing the same 'law' that Radbruch refers to. In believing that 'law' can be discussed in a neutral manner, abstracting from the aims it (should) pursue, these positivists take a purely descriptive approach, which Radbruch would find untenable due to the normative nature of 'law'. Notwithstanding Radbruch's normative position he should not be understood as imposing a specific concept of justice and public interest on the 'law'. His analysis only means that a law that no longer aims for justice or public interest should not be given the credit of being 'law' at all. ${ }^{42}$ This, however, is not merely a theoretical exercise. The decision not to grant a law the character of being 'law' is - for Radbruch - a matter of personal courage, ultimately taken in one's individual conscience. This is where Radbruch agrees with Schmitt's opinion about the 'exacting

\footnotetext{
${ }^{40}$ Radbruch (1950) at 336: '(...) dann fehlt diesen Gesetzen die Geltung, dann schuldet das Volk ihnen keinen Gehorsam, dann müssen auch die Juristen den Mut finden, ihnen den Rechtscharacter abzusprechen'.

41 Note that in the German text Radbruch opposes Gesetz and Recht, which would translate into English as opposing law (statute or legal code) and law (in its generic sense of a legal order). I have translated Gesetze as laws and Recht as 'law', because the role of statutes in continental law is different from their role in common law jurisdictions where case law can function similarly to enacted law. I am sure Radbruch would claim that his priority of 'law' over laws also regards case law that is unjust or in violation of the public good to an extent warranting a rejection of such case law as 'law'.

42 According to Radbruch, the idea of justice (a regulative principle) is not be confused with the concept of law (a descriptive element). Although law should aim for justice, we can never take for granted that it achieves this aim, cf. Radbruch (1950) at 123-130. This brings Radbruch close to Derrida's distinction between justice as something the law cannot provide but should be aiming for, cf. Derrida (1989-1990).
} 
moral decision' that is required of the sovereign in times of emergency. ${ }^{43}$ One could turn Schmitt inside out by confirming that 'sovereign is whoever decides on the exception', even if this decision is made by an individual unable to seize power, incapable of subjecting others to her decision. The exception in that case is the exception to the rule that laws are always 'law', and the individual concerned is the lawyer, judge, prosecutor or any other government official called upon to apply laws that violate the fundamental directionality towards justice, legal certainty and the public good. The sovereignty that is manifested here is a subversive type of personal sovereignty, entailing the risk of imprisonment, harm or even death. Can we require government officials to take emergency measures at the cost of their own safety; must the official act in accordance with the aims of the 'law' (justice, the public good and legal certainty), even if this violates the 'laws' of the existing order? Can this official be held criminally liable if he does not seize the opportunity to engage in this type of subversive personal sovereignty?

\section{Jurisdiction in a Legal Vacuum?}

\section{Introduction: Two Questions}

In this section, building on the previous discussions, I will respond to two questions. Firstly, the question of to what extent the indeterminacy of an emergency calls for inherently unlimited powers of the state, implying there can be no such thing as criminal jurisdiction during a state of emergency. Second, if criminal jurisdiction is not in contradiction with the state of emergency, the question arises what punishment could mean when the offense is committed during the suspension of the legal order.

\section{Indeterminacy and Unlimited Powers}

In The New Police Science. The Police Power in Domestic and International Governance, ${ }^{44}$ a series of essays have been collected, dealing with what is termed the 'police' in the old sense of the word: government or administration. Many of the contributions discuss the ordinary and exceptional 'police power' in terms of its pertinent indeterminacy, pointing out that this implies unlimited powers for 'police' in the sense of government. They suggest that because the power of 'police' cannot be defined, its competence cannot be limited. In a review of this challenging volume I have objected to the equivalence of definitional indeterminacy and practical limitlessness. ${ }^{45}$ Firstly, this equivalence does not discriminate between conceptual underdeterminacy and actual indeterminacy. Terms like 'police' and 'emergency' are difficult to define because there is no consensus on their usage, which is often evaluative and depends on the context. ${ }^{46}$ This, however, does not mean that such concepts are indefinable. Rather, their meaning is underdetermined in the sense that they denote phenomena that have a family resemblance without necessarily sharing a common core. Though ultimate agreement on what counts as the power of

\footnotetext{
43 Supra note 12.

44 Dubber and Valverde (2006).

45 Hildebrandt (2008) at 111-114.

${ }^{46}$ Cf. Gallie (1956).
} 
police' or 'a state of emergency' will never be achieved, this does not mean that the concept can mean just anything or everything. The meaning of the term will develop in the course of its usage, but to make sense we cannot use it in whatever way we like. In fact, every time we use the term, we decide on its meaning. Because the concept is underdetermined, every usage is a new determination of the concept. This is not only the case for concepts like 'police' or 'emergency', but also for concepts like 'law' and 'legal order'. The underdeterminacy of the concept of emergency does not eo ipso rule out that government powers are limited during a state of emergency. This argument can be reinforced by referring to my discussion of Schmitt's position. In separating legal norm and legal decision, he creates the possibility to oppose law (as powerless normativity) to politics (as ultimate decisionism), claiming that in the case of an emergency 'the state remains whereas law recedes'. ${ }^{47}$ My point is that this could indeed be the case, but that it is not a necessary development. The suggestion that the powers of the sovereign are necessarily unlimited is also flawed in as far as this is concluded after comparing sovereign power with the force of law, suggesting that because law is a matter of strict definition it cannot limit a sovereign that defies definition. The comparison builds on a discretionary conception of police powers and a legalist conception of law. ${ }^{48}$ However, just like "police power' the 'law' is fundamentally underdetermined. Legalist understandings of law hide the intricate relationship between norm and decision (normativity and authority) that in fact indicates that in the end the sovereign depends as much on the 'law' as the 'law' depends on the sovereign. Whoever tries to determine the priority of chicken or egg here, misses the point.

As pointed out earlier, Schmitt's urge to isolate the decision and grant it priority was directed against Kelsen's isolation of the legal norm. Their positions present us with two sides of the same coin. While Schmitt's position seems to endorse-if not justify-an irrational seizure of power beyond the rule of law, Kelsen's position seems to endorse-if not justify - an overly systematic rationalist understanding of state. ${ }^{49}$ While both claim that their objective is only to describe the way things are, they actually make distinctions that 'make' a difference ${ }^{50}$ : in constructing a world that is vulnerable to being high jacked by authoritarian and totalitarian political agendas these distinctions may be creating the preconditions for such agendas to flourish in times of emergency. This would mean that the analysis of legal and political issues is not an innocent endeavour: analytical description is capable of changing the world as much as normative prescriptions. Perhaps the description - the way we claim to perceive the world-is even more fundamental in designing our shared destiny than the 'application-layer' of moral or legal considerations. Whether the

\footnotetext{
47 Supra note 13.

48 Legalist conceptions of law can be found in legal theory (formal positivism, e.g. Kelsen) and in constitutional law (the formal conception of the Rechtsstaat and the French Etat légal), cf. Chevallier (1994) at 14-54). One can find parallels in nineteenth century UK stare decisis and US legal formalism.

${ }^{49}$ For Kelsen the concept of the Rechtsstaat is a tautology, because the state is a legal construct. Cf. Kelsen (1999), especially Part II, section IA, The State as a Real (Sociological) or Juristic Entity, at 181-191.

${ }^{50}$ Cf. Robert Merton's famous 'self-fulfilling prophecy': 'if men define situations as real, they become real in their consequences', taken from W.I. Thomas and Dorothy Swaine Thomas, The Child in America: Behaviour Problems and Programs (1928), at 572. Merton elaborated the idea for the social sciences in Merton (1995). Merton as well as Thomas refer to mistaken or biased perceptions that become real because they are thought to be real. From an epistemological perspective it seems more interesting to follow Pearce's pragmatist maxim: 'Consider what effects that might conceivably have practical bearings we conceive the object of our conception to have: then, our conception of those effects is the whole of our conception of the object', Peirce and Turrisi (1997) at 111.
} 
state (Schmitt's sovereign) remains while the law (Kelsen's formal system of legal rules) recedes, thus remains to be seen. If we are capable of looking at power and law as both informed by norm and decision, both containing irreducible moments of creative adaption to new contexts, we may prevent the collapse of the rule of law in the face of challenges to the monopoly of violence. The power of police (Schmitt's sovereign) as well as the law (especially the ius puniendi) in fact both depend on the monopoly of violence. Challenges of that monopoly thus require adequate responses on both accounts.

\section{The Meaning of Punishment in Times of Indeterminate Emergency}

Does it make sense to punish a person if he committed an offense at a time when the legal order was suspended due to an emergency? Even Schmitt acknowledged that the act of suspending the entire existing order does not mean that anarchy and chaos 'rule'. Instead he claims that 'order in the juristic sense still prevails even if it is not of the ordinary kind'. ${ }^{51}$ I think that what he calls 'the juristic sense' can be located in the decision to counter the threat(s) to the monopoly on violence. As argued above this means that new legal norms are created, and perhaps the question is whether they are created ex nihilo, reinforcing the radical indeterminacy that seems inherent in a situation of emergency. The creation of new legal norms does not only regard enacting new decrees. The point is that whatever actions are undertaken to sustain or seize the monopoly on violence, to count as actions they need to embody rules in the elementary sense of Wittgenstein's discussion of what it is to follow a rule. These rules need not pre-exist the decision. Especially in the case of an emergency new rules will be invented, though those who decide may not be aware of the rules implied in their interventions. However, the fact that the rules did not pre-exist the actions as explicit prescriptions does not mean that they have been created ex nihilo. Two candidates will co-constitute these implicit norms (implicitly given in the intervention): necessity (as described above) and the political orientation of whoever acts (inclined either to restore or establish constitutional democracy, to create a basis for authoritarian or totalitarian rule, or to create or reinforce a situation in which certain economic monopolies can be privileged). ${ }^{52}$ As argued above, a retributive theory of punishment cannot account for criminal liability in a situation wherein necessity creates a legal void or establishes new legal norms. The reason is that no theoretical justification can be given for such punishment, due to the fact that retribution faces the past in terms of its past: it requires explicit rules that criminalise specific behaviours before the incriminated action takes place. The principle of legality and the implied notion of lex certa rule out what can then only be understood as retroactive criminalisation.

Could a communicative theory of punishment - as argued by Duff_make sense of criminal liability during a suspended legal order? ${ }^{53}$ The core of a communicative theory is (1) the reciprocity between punisher and offender, even if this reciprocity must not be understood as implying equality or symmetry and (2) the inclusiveness that allows the punisher to make an appeal to the offender as a fellow instead of an enemy. As to the first,

\footnotetext{
51 Schmitt, supra note 13 .

52 About a prolonged state of emergency that enables the institution of a global empire, built on the logic of an anonymous neo-liberal economic world system that turns states into instruments of a global capitalism: Hardt and Negri (2000). See supra footnote 17 about the usage of emergency interventions for economic reasons.

53 Duff (2001).
} 
is it possible to reconstruct this reciprocity in the case of an emergency, taking into account that the ex ante, ad hoc and ex post perspectives of both the punisher and the 'offender' differ radically due to the indeterminacy of the emergency (including the indeterminacy of whether, when and which legal order is established after the emergency is terminated)? And, if this is a reconstruction, does that not imply that the communication is initiated only after the emergency, thus not having any appeal during the state of exception? In this case reconstructive thinking is not a matter of taking the ex post perspective of the court that is called to judge the emergency interventions of a government official. It is a metaperspective that attempts to take account of the relevant ex ante, ad hoc as well as ex post perspectives, in order to evaluate whether the actions of the defendant can still be understood as part of a communicative rationality that implies censure of actions that violate legal certainty, justice or the public good. In fact, this raises the second point, because a communicative rationality seems to presume a community of fellow citizens, who share jurisdiction, capable of holding each other accountable for violations of legitimate expectations. Is this not precisely what is lacking in a state of emergency? Must we not acknowledge that the lack of legal certainty in itself creates a legal void that rules our criminal accountability? I will save the issue of legal certainty for the last section and move to the question of the violation of justice and the public good.

Can we launch an appeal to a government official as a fellow (citizen?) after she has flouted fundamental tenets of constitutional democracy by seizing power in ways that degrade former fellow citizens, using them as an instrument to further her own control? Or, more broadly, what if this official uses emergency powers to further the control of a state or any other institution that is no longer limited in its exercise of power? Should we not accept that this person is not an adversary but an enemy of constitutional democracyruling out criminal law as we know it? Maybe we should accept Schmitt's concept of the political here, which he defines as the distinction between friend and enemy. ${ }^{54}$ After all, if we wish to hold government authorities accountable for their interventions during the state of emergency, we need to acknowledge that in as far as they have willingly offended basic tenets of constitutional democracy they have caused harm to the social and legal infrastructure of communication that constitutes the democratic constitutional state. In that case one could argue that we need an exclusionary approach that defines as enemies those who behave as enemies. ${ }^{55}$

Building on the distinction between friend and enemy, though without reference to Schmitt, Günther Jakobs has argued for a separation of the Bürgerstrafrecht and a Feindstrafrecht. He defines the Bürgerstrafrecht as the criminal law for citizens, of which the function is the negation-Widerspruch-of the violation of the legal norm. What he calls a Feindstrafrecht is defined as a criminal law for enemies, of which the function is to ward off a danger. To justify the distinction he refers to the social contract theories of Rousseau, Fichte, Hobbes and Kant, and proceeds to define whoever places himself outside the social contract as an enemy, thus professing an exclusionary approach for those that challenge the hegemony of an existing social contract. He also warns against the present mixing of both types of criminal law because the logic of the Feindstrafrecht will contaminate the safeguards of the Bürgerstrafrecht. ${ }^{56}$ His point is not-as in the case of

\footnotetext{
54 Schmitt (1996), Chap. 2.

55 This is not Schmitt's point, as he basically claims that a people (an 'us') can only define itself in the act of deciding who is one's enemy. This would imply that we need enemies to become a people, which is certainly not the point I want to make.

56 Jakobs (2004).
} 
Rousseau and Fichte - that any criminal offender places himself outside the social contract, but-more in line with Hobbes and Kant - that certain types of serious crime must be understood as placing oneself outside the social contract. For Jakobs those that commit acts of international terrorism are enemies, warranting and justifying a different approach, somewhere between a defendant in a criminal trial and a prisoner of war. ${ }^{57}$ One could similarly consider government officials who either seize power to rule out constitutional constraints or obey orders that violate the rule of law as enemies whose actions cannot fall under the criminal jurisdiction. Jakobs can be understood as propagating a communicative theory of punishment for 'normal' criminal offenses, claiming that international terrorism basically demonstrates a break-down of all communication between fellow-citizens, or a point in time that demonstrates that no communication exists between the insiders of the legal order and its 'enemy combatants'. Similarly government officials whose behaviour flouts the rule of law can be seen as actively destroying the communication that is pivotal for a constitutional democracy, thus placing themselves outside the confines of its jurisdiction. This could imply that the core of an inclusive communicative theory of punishment depends on exclusion: either restricting itself to a particular community or to a particular territorial state. Once the community or the state is at a point of breakdown, those that (further) endanger its core tenets must not be treated as criminal defendants, but must be qualified as enemies. This non-communicative implication would regard as enemies instead of adversaries both the terrorist who brings about the state of emergency and the government official who seizes power in a way that obstructs a return to the constitutional democratic order. ${ }^{58}$ Treating them as criminal defendants could be giving them too much credit, or even, not taking them serious as the type of 'other' they are.

In fact I think that treating those who behave like enemies as enemies is a form of communication, just like flying an airplane into the World Trade Centre is a very powerful form of communication. Some would argue that this is not communication but expression, aimed to express disgust with whatever the Twin Towers were thought to stand for. Such expression would then need a counter-expression, at least equal in force, to nullify the message that this intervention expresses. I find the use of the term expression in this case artificial if it is meant to deny that this expression communicates hatred and contempt to those that suffer the consequences. This essentially means that the response is a matter of choice: one can understand the attack as an ultimate rejection of communication and hit back with all the force one can master to negate the violation of public and private security, or one can understand the attack as the most gruesome communication a community can receive and-while preparing to identify the offenders in order to punish them-attempt to 'construct the 'them' in such a way that it is no longer perceived as an enemy to be destroyed, but as an 'adversary', that is, somebody whose ideas we combat but whose right to defend those ideas we do not put into question' ${ }^{59}$ The first reaction implies revenge and

\footnotetext{
57 Agamben (2005) at 3, has already pointed out that the problem with Guantánomo is that the inmates lack the protection of both the criminal law and of the status of prisoners of war. The in-between of defendant and prisoner of war is a legal void.

58 On the difference between an enemy and an adversary, see Mouffe (2000) at 13.

59 Mouffe (2000) at 101-102. It would be an interesting challenge to investigate how Duff's communicative theory of punishment relates to Habermas' theory of communicative rationality and Mouffe's 'agonistic pluralism'. See also infra note 62. Cp. Kennedy (1998), who notes, at 103, that Schmitt's Concept of the Political 'suggests two aspects of the public: the people as a political agent and the people as beings whose lives are at stake $(. .$.$) '.$
} 
could lead to a feud on a global scale, in the end annihilating the entire global order ${ }^{60}$ It is interesting to note that according to an analysis of Harvard researchers in 2002 'the disposition to become a terrorist does not follow from being poor or being illiterate but rather from being humiliated. Abu Ghraib and Guantanamo are symbols of that humiliation'. ${ }^{61}$ This seems to confirm that the second reaction is more robust. It implies taking constitutional democracy serious as a form of 'agonistic pluralism', accepting the challenge of turning enemies into adversaries. ${ }^{62}$ This—of course-does not mean that we should mistake our enemies for adversaries; it only means that in defending constitutional democracy we must not discard its basic tenets. It suggests that the confrontation with whoever presents himself as an enemy invites the hard work of turning him into an adversary. Bringing the offenders before a criminal court would be one way to do this. Another way to work at this could be to undertake a reflection on the extent to which we have been behaving like an enemy towards those who have turned on us, acknowledging that communication is a reciprocal affair. Again this is not to deny that we should also have the courage of taking an exclusionary perspective towards those that behave like enemies, while still striving for inclusion and communication.

The meaning of punishment in times of emergency could well be that it communicates censure beyond the limits of the community, ${ }^{63}$ taking the risk of confronting an enemy who is not open to communication of censure. For this reason I do not think a separate Feindstrafrecht is advisable, because it petrifies the distinction between enemy and adversary, drawing strict lines around 'our' community. Taking the risk of creating the possibility for an enemy to respond to our censure by becoming an adversary (becoming one of us) will include the risk that we are stuck with an enemy in our midst (who defines herself as not being one of us). I think, however, that taking that risk is crucial for the survival of constitutional democracy in times of emergency, because risking a sustained non-communication is a far more dangerous option in the era of globalisation. Dreaming about locking up communities is simply illusionary in a world that depends on mobility and transnational exchange.

This leaves us with the question of how we can judge the behaviour of government officials who have outstepped their competence in times of emergency. In the concluding section we will confront one of the most difficult issues raised by the indeterminacy of the state of exception: the question of legal certainty.

\footnotetext{
${ }^{60}$ Hoebel (1971), at 500-511 (about the threat of feud as a fierce constraint on the exercise of revenge, which is thought to threaten both clans with extinction).

61 Hellwig (2007). Hellwig is President (2004) of the Bars and Law Societies of Europe (CCBE). Also Harvard Magazine (2002).

62 The concept of 'agonistic pluralism' is Mouffe's (2000) at 80-107. She uses it to move beyond the rationalist assumptions of deliberative democracy that wrongly take for granted that politics is a matter of constructing a rational consensus, incapable of coping with real dissensus between incompatible positions that warrant compromise as well as recognition that the other's perspective cannot be reduced to a biased version of one's own standpoint. See on different models of democratic theory Hildebrandt and Gutwirth (2007).

63 Criminal jurisdiction seems to presume a community. However, this community is not only a necessary precondition-it is also always the product of criminal jurisdiction. There is-again-no chicken or egg here. Addressing offenders outside the community who cause harm within the community may be productive in the sense of integrating the outsiders into the community.
} 


\section{Conclusions: Judgment Against Which Standards?}

The final question can now be confronted: to what extent does the indeterminacy inherent in a case of emergency jeopardise criminal liability, even suggesting immunity because legal uncertainty blurs the standards against which the incriminated actions are to be judged?

In his pre-war writings Radbruch had argued that legal certainty-as the ultimate guarantee of order per se-has a measure of priority over justice and purposiveness, even if he never took Schmitt's extreme position. Other than those who claim that Radbruch's post-war standpoint differs radically from his pre-war celebration of the positivity of the law, ${ }^{64}$ I think that for Radbruch the antinomian core of the law always ruled out an absolute priority for either legal certainty, justice or purposiveness. The terror of the Nazis confirmed that whereas the insecurity of the Weimar Republic turned legal certainty into a high priority, the horror scenario of arbitrary application of positive laws during Nazi rule required another priority, being that of justice (equality before the law). Paraphrasing Radbruch we can say that when certain interventions of government officials cannot be understood as aiming for equal treatment or can no longer be seen as intent on furthering the public good, it should be possible to call them to account in a court of law. One of the advantages of opting for a criminal—instead of a military—court would be that the person so charged has the standing of a legal subject and is provided with the means to defend herself against the charge, opening a debate on whether her actions do in fact demonstrate gruesome violations of the order of constitutional democracy during its suspension.

The crucial point here is that we do not know how a state of emergency will develop and who will be faced with what choices of action. As argued above, however, the indeterminacy of a future emergency should not paralyse us, nor tempt us into enacting general rules for dealing with uncertainties that will require unanticipated interventions. Indeterminacy is the opposite of necessity; it leaves many options open, including the extreme situation of strict necessity that completely determines one's actions. Whether and when this extreme situation will occur remains to be seen. In the mean time the indeterminacy of an emergency does not imply necessarily unlimited powers for whoever seizes the power to safeguard or establish order. However, because the standards against which the actions of government officials will be judged cannot be anticipated in great detail, we must accept the fact that only grotesque violations of the suspended constitutional democratic order can be confronted in a criminal court and acknowledge that any attempt to provide strict guidance by means of ex ante legislation does not make sense.

This implies that a minister who orders the shooting of a civil airplane that may be used for a terrorist attack, threatening the lives of many innocent citizens, could indeed be called to account in a criminal court for the deaths she caused. Though I can imagine that a judge would find reasons for justification or lack of mens rea in the case of an official who took the responsibility of shooting the plane (or having it shot), I also find myself in agreement with the Bundesverfassungsgerichtshof where it rejected a general competence for a Minister to take such a decision. ${ }^{65}$ To grant that competence by law is a different matter altogether, because it allows the legislator to instrumentalize the lives of those in the plane

\footnotetext{
64 See e.g. Mertens (2006), who speaks of Radbruch's 'conversion' from legal positivism to 'natural law'. Cp. Leawoods (2000) at 501-503, who argues that Radbruch's shift after the war is a refinement of his previous theory and certainly not in contradiction with it.

65 BVerfG, 1 BvR 357/05 of 15.2.2006, available in English at: http://www.bverfg.de/entscheidungen/ rs20060215_1bvr035705en.html (last downloaded at 14.1.2010).
} 
as the result of a generally applicable calculus. There is a similarity here with the torture cases judged by the Israeli High Court of Justice. The court rejected the idea that the authority to provide directives for interrogations that violate human dignity can be derived from the defence of necessity that is available to an interrogator in the case of the 'ticking bomb scenario' ex post facto. ${ }^{66}$ As has been suggested, ${ }^{67}$ abstract discussions of what is allowed and what is not-based on one or more conditions that can be decided upon beforehand-make little sense and will not provide safeguards against lawless unjustified emergency operations. Instead, a detailed investigation into the interrogations that are at stake, facing the security threats that triggered them, should generate a more robust network of cases that may in fact prevent arbitrary rule in times of emergency. At the same time we must acknowledge that once the state of exception becomes the rule, courts may have very little room to rule out systemic violations of human rights. ${ }^{68}$ This suggests that criminal jurisdiction over governmental actions during a state of emergency does require that the state of emergency has ended its hold on the judiciary.

Open Access This article is distributed under the terms of the Creative Commons Attribution Noncommercial License which permits any noncommercial use, distribution, and reproduction in any medium, provided the original author(s) and source are credited.

\section{References}

Agamben, G. (2005). State of exception. Chicago: University of Chicago Press.

Barak, A. (2002). A judge on judging: The role of a supreme court in a democracy. Harvard Law Review, $116,75-105$.

Benjamin, W., Bullock, M. P., et al. (1996). Selected writings. Cambridge: Belknap Press.

Chevallier, J. (1994). L'État de droit. Paris: Montchrestien.

Cohen, B. (2001). Democracy and the mis-rule of law: The Israeli legal system's failure to prevent torture in the occupied territories. Indiana International and Comparative Law Review, 12, 75-105.

Cristi, F. R. (1984). Hayek and schmitt on the rule of law. Canadian Journal of Political Science, 17(3), $521-535$.

Derrida, J. (1989-1990). Force of law: The 'mystical foundation of authority'. Cardozo Law Review, 11, $920-1046$.

Dewey, J. (1916). The logic of judgments of practice, Chap. 14. In J. Dewey (Ed.), Essays in experimental logic (pp. 335-442). Chicago: University of Chicago Press.

Dubber, M. D., \& Valverde, M. (Eds.). (2006). The new police science. The police science in domestic and international governance. Stanford: Stanford University Press.

Duff, R. A. (2001). Punishment, communication, and community. Oxford: Oxford University Press.

Dworkin, R. (1991). Law's empire. Fontana: Glasgow.

Fish, S. (1982). Working on the Chain Gang: Interpretation in law and literature. Texas Law Review, 60, 551-606.

Foqué, R., \& 't Hart, A. C. (1990). Instrumentaliteit en rechtsbescherming. Arnhem Antwerpen: Gouda Quint Kluwer Rechtswetenschappen.

Fuller, L. (1949). The case of the Speluncan explorers. Harvard Law Review, 4(62), 616.

Fuller, L. (1985). Positivism and Fidelity to Law: A Reply to Professor Hart. Harvard Law Review, 4(71), 630-672.

Gallie, W. B. (1956). Essentially contested concepts. Proceedings of the Aristotelian Society, 56, 167-198.

Gay, P. (2001). Weimar culture: The outsider as insider. New York: W.W. Norton.

Glastra van Loon, J. F. (1958). Rules and commands, LXVII. Mind, 268, 514-521.

Hardt, M., \& Negri, A. (2000). Empire. Cambridge, Mass: Harvard University Press.

\footnotetext{
${ }^{66}$ The Public Committee v. The Government of Israel, HCJ 5100/94, 15 July 1999. The court did hold, however, that such authority could be based on legislation explicitly granting such competences.

${ }^{67}$ Barak (2002).

${ }^{68}$ Cohen (2001).
} 
Harvard Magazine. (2002). Understanding Terrorism. A Harvard Magazine Roundtable, Harvard Magazine (February), at 36-49 and 99-103.

Hellwig, H.-J. (2007). Anti-terrorism legislation-Effects, causes and concerns. Available at http://www. dbjur.de/content/index.php?id=11,29,1,0.

Hildebrandt, M. (2002). Straf(begrip) en procesbeginsel. Een onderzoek naar de betekenis van straf en strafbegrip en naar de waarde van het procesbeginsel. Deventer: Kluwer/Sanders Instituut.

Hildebrandt, M. (2006). Trial and 'Fair Trial': From peer to subject to citizen. In A. Duff, L. Farmer, S. Marshall \& V. Tadros (Eds.), The trial on trial. Judgment and calling to account, vol 2 (pp. 15-37). Oxford and Portland: Oregon, Hart.

Hildebrandt, M. (2008). Governance, governamentality, police and justice: A new science of police. Buffalo law review, 56, 557-598.

Hildebrandt, M., \& Gutwirth, S. (2007). (Re)presentation: pTA citizens' juries and the jury trial. Utrecht Law Review, 3(1), 24-40.

Hoebel, A. E. (1971). Feud: Concept, reality and method in the study of primitive law. In A. R. Desai (Ed.), Essays on modernization of underdeveloped societies (pp. 500-511). Bombay: Thacker.

Jakobs, G. (2004). Bürgerstrafrecht und Feindstrafrecht, HRRS, 5(5), 88-95.

Kelsen, H. (1999). General theory of law and state. Union, N.J., Lawbook Exchange.

Kennedy, E. (1998). Hostis not inimicus. In D. Dyzenhaus (Ed.), Law as politics: Carl Schmitt's critique of liberalism (pp. 92-108). Durham, NC: Duke University Press.

Leawoods, H. (2000). Gustav Radbruch. An extraordinary philosopher of law. Journal of Law and Philosophy, 2, 489-516.

Maus, I. (1998). The 1933 "Break" in Carl Schmitt's theory. In D. Dyzenhaus (Ed.), Law as politics: Carl Schmitt's critique of liberalism (pp. 196-216). Durham, NC: Duke University Press.

McCormick, J. P. (1998). The dilemmas of dictatorship. Carl Schmitt and constitutional emergency powers. In D. Dyzenhaus (Ed.), Law as politics: Carl Schmitt's critique of liberalism (pp. 217-251). Durham, NC: Duke University Press.

Meinecke, F. (1998). Machiavellism: The doctrine of raison d'État and its place in modern history. New Brunswick, NJ: Transaction Publishers.

Mertens, T. (2006). But was it law? C. Joerges, N. S. Ghaleigh (Eds.), Darker legacies of law in Europe: The shadow of national socialism and fascism over Europe and its legal traditions. In: German Law Journal, 2(7), 191-197.

Merton, R. K. (1995) The Thomas theorem and the Matthew effect. Social Forces, 4(74), $379-42$.

Mouffe, C. (2000). The democractic paradox. London, New York: Verso.

Peirce, C. S., \& Turrisi, P. A. (1997). Pragmatism as a principle and method of right thinking: The 1903 Harvard lectures on pragmatism. Albany: State University of New York Press.

Radbruch, G. (1950). Rechtsphilosophie. Herausgegeven von Erik Wolf. Stuttgart: K.F. Koehler.

Scheuermann, W. E. (1994). The permanent state of emergency, Chap. 5. In Between the norm and the exception. The Frankfurt school and the rule of law. Cambridge, MA: MIT Press.

Schmitt, C. (1996). The concept of the political. Chicago: University of Chicago Press.

Schmitt, C. (2005). Political theology: Four chapters on the concept of sovereignty. Chicago: University of Chicago Press.

Taylor, C. (1995). To follow a rule. In C. Taylor (Ed.), Philosophical arguments (pp. 165-181). Cambridge, Mass: Harvard University Press.

Winch, P. (1958). The idea of a social science. London and Henley: Routledge \& Kegan Paul.

Zöller, V. (2004). Liberty dies by inches: German counter-terrorism measures and human rights. German Law Journal, 5(5), 469-494. 